\title{
Reproductive concerns of children and adolescents with cancer: challenges and potential solutions
}

This article was published in the following Dove Press journal:

Clinical Oncology in Adolescents and Young Adults

12 June 2013

Number of times this article has been viewed

\section{Catharyn Stern' \\ Rachel Conyers ${ }^{2}$ \\ Lisa Orme ${ }^{2}$ \\ Shlomi Barak ${ }^{1,3}$ \\ Franca Agresta' \\ John Seymour ${ }^{2}$}

'Melbourne IVF and Royal Women's Hospital, ${ }^{2}$ Peter MacCallum Cancer Centre, Melbourne, and University of Melbourne, ${ }^{3}$ Department of Obstetrics and Gynaecology, University of Melbourne,

Melbourne, Victoria, Australia
Correspondence: Catharyn (Kate) Stern Suite $3 / 320$ Victoria Parade, East Melbourne, VA 3002, Australia

Tel +61039415 I838

Fax +6I 0394162581

Email kate.stern@mivf.com.au
Abstract: The diagnosis of a potentially life-threatening cancer is one of the most traumatic events that can befall a young person and his or her family. However, fortunately, most young people will survive their cancer and its treatment and go on to lead a long and healthy life, with an appropriate expectation of being able to have their own genetic family. However, cancer treatment, including surgery, chemotherapy, and radiotherapy, can have temporary and permanent effects on fertility, including damage to the uterus and pituitary gland, and reduction, or obliteration, of gonadal function, with consequential loss of oocytes or spermatozoa, which may result in ovarian or testicular failure. As the gamete pool is nonrenewable, permanent gonadal failure precludes subsequent fertility with a patient's own genetic material. Awareness and acknowledgement of the likely future fertility implications of cancer treatment is an essential part of any discussion about proposed therapies. Options for girls and young women include freezing mature oocytes and ovarian tissue, as well as attempting to protect the ovaries from the gonadotoxic effects of treatment. Options for boys and young men include semen collection and storage as well as testicular biopsy with freezing of testicular tissue or spermatozoa retrieved from the tissue. Fertility options can now be offered with increasing optimism about success and the provision of a genuine opportunity for having a family. While the initiation of cancer treatment is sometimes truly urgent, the opportunity for a detailed discussion about implications for fertility is of paramount importance for patients and their families and provides both reassurance and optimism about the future.

Keywords: fertility preservation, chemotherapy, radiotherapy, ovarian failure, testicular failure, gonadal function

\section{Introduction}

With improvements in cancer therapies, most children and adolescents can now expect to survive their cancer and lead long and healthy lives. ${ }^{1}$ An important element of this expectation is that they will be able to have their own family. This means that as well as provision of a "disease-free state," physicians should aim to provide their young patients with the opportunity for optimal quality of life, which includes a commitment to preserving and protecting fertility. Many treatments, including radiation and highdose chemotherapy, can have severely gonadotoxic effects in children and adolescents, resulting in sterility and permanent infertility, either in the acute phase or with later onset involving impaired fertility or premature ovarian failure (POF). Discussion of the fertility implications of cancer treatment is thus an essential part of pretreatment counseling. Specialists and other teams must be not only aware of the strategies currently available for fertility preservation but also familiar with the risks, logistic 
requirements, and side effects, and the potential for the success of these options. Early discussion with a fertility specialist will allow the patient and his/her family the opportunity to ask questions and voice concerns, and to become well informed about fertility preservation options in conjunction with the treating physician.

\section{Prevalence of common cancers in children and adolescents}

One in 250 young adults is a long-term survivor of childhood cancer. ${ }^{2}$ The estimated number of adolescent and young adult (AYA) patients (aged 15-29 years) diagnosed with invasive cancer (including melanoma) in the USA in 2012 was $99,650 .{ }^{1}$ This accounts for $2 \%$ of all invasive cancers in the total population. In contrast, pediatric patients (aged 0-14 years) were found to account for only $1 \%$ of all invasive cancers $(n=36,770)$ in the same year. ${ }^{1}$ The criteria for consideration of patients as "AYA" - in particular, the upper age of inclusion - varies between jurisdictions, with the upper age being 39 years in US figures and 29 years in Australian figures. ${ }^{3}$

The disease spectrum changes dramatically across the age range - from the embryonal tumors of childhood (eg, neuroblastoma, medulloblastoma, and rhabdomyosarcoma), to a higher frequency of epithelial cancers more typically associated with aging (eg, breast cancer, colorectal cancer, and melanoma). According to the most recent Australian Institute of Health and Welfare report, ${ }^{3}$ which reported data for AYA patients (15-29 years) for 2003-2007, cancers with the highest incidence included malignant melanoma, Hodgkin's lymphoma, thyroid carcinoma, non-Hodgkin's lymphoma, colorectal carcinoma, and breast carcinoma, which is consistent with global findings. ${ }^{4}$ In pediatric and adolescent patients (aged 0-19 years), the most common cancer is acute lymphoblastic leukemia, followed by brain tumors, non-Hodgkin's lymphoma, Hodgkin's lymphoma, and bone and soft tissue tumors. ${ }^{5}$ These trends regarding commonest malignancies have remained constant over the last decade. ${ }^{5,6}$

\section{Risk to fertility with female cancer treatments Female fertility and the effects of radiation and chemotherapy regimens}

It is still generally accepted that the pool of primordial follicles is finite. The maximal number occurs midway through fetal life, followed by subsequent depletion through both atresia and maturation. Atresia becomes accelerated later in reproductive life, and when the population of follicles declines below a critical threshold, reproductive potential diminishes with development of infertility and eventually sterility. ${ }^{7,8}$ The effect of many cancer treatments is related to the decline in the number of these nonrenewable primordial follicles as well as a reduction in the number of larger, maturing follicles. ${ }^{9}$ The consequential impact on reproductive potential depends on the age of the patient, the type of treatment, and the duration and total cumulative dose of treatment administered. ${ }^{10}$

The exact mechanism by which chemotherapy causes loss of primordial follicles is poorly understood. ${ }^{11}$ Most anticancer cytotoxic drugs exert their effects on dividing cells and the toxic effects include inhibition of cell division and adverse effects on DNA function within the dividing granulosa and theca cells of the ovary, as well as on the oocytes within the follicles. It is possible that loss of the growing follicle pool population will result in increased activation of more primordial follicles that may then themselves become vulnerable to damage in subsequent treatment cycles - this has been called the follicle "burn-out" concept. ${ }^{12}$ Impairment of angiogenesis may also contribute to loss of primordial follicles. ${ }^{13}$

The risk of premature menopause (PM) correlates with both drug type and drug dose, with older patients being more susceptible, and thus requiring a lower cumulative drug dose to manifest ovarian failure. ${ }^{14}$ Specific alkylating agents such as busulfan, cisplatin, cyclophosphamide, ifosfamide, procarbazine, and, historically - most potently - nitrogen mustard have been linked to both acute/temporary ovarian failure (TOF) and POF. These drugs are administered for the treatment of various tumor types, with or without concomitant radiotherapy, and are particularly noxious to fertility when given as part of high-dose chemotherapyconditioning regimens for autologous or allogeneic bone marrow transplants. ${ }^{6,15}$ The cumulative alkylating agent dose heavily affects ovarian dysfunction, with the actuarial 10-year risk of POF reported as being as high as $64 \%$ with doses of cyclophosphamide $>8.4 \mathrm{~g} / \mathrm{m}^{2} .{ }^{16}$ Lower doses of alkylator $\left(<4.2 \mathrm{gm} / \mathrm{m}^{2}\right)$ carry a 10 -year actuarial risk of POF of $15 \%{ }^{16}$

Therapeutic delivery of ionizing radiation either in the form of total body irradiation (TBI), as is used as part of high-dose therapy and marrow stem cell transplantation, or abdomino-pelvic radiation, such as may be used for sarcomas or lymphomas, can cause permanent damage to the ovaries and the uterus, with the extent of damage determined by the dose and field, fractionation, and patient age. The resultant effect on the follicles can be either TOF or POF, with the risk related to age, schedule, and dose. ${ }^{17}$ 
Predictive models now allow physicians to quantify risk of infertility based on patient age at exposure and radiation dose to the ovaries. ${ }^{18,19}$ A dose of 10-30 Gray (Gy) in patients treated during childhood/adolescence has been shown to almost always result in TOF and very commonly POF. ${ }^{19,20}$ This finding has been supported by the Childhood Cancer Survivorship Study, which revealed that $70 \%$ patients treated with $>20$ Gy developed TOF. The ovaries are sensitive to radiation, with doses as small as $1-2000$ cGy resulting in ovarian dysfunction in young patients. ${ }^{21}$ Given this finding, it is not surprising that ovarian failure occurs in $90 \%$ of patients treated with TBI at doses of 10.00-15.75 Gy and in $97 \%$ of patients treated with whole abdominal irradiation (20-30 Gy) in childhood or adolescence. ${ }^{22,23}$

Radiation has been shown to also result in uterine dysfunction and small-for-gestational-age pregnancies (SGA). ${ }^{24,25}$ Radiotherapy to the uterus causes damage to uterine vasculature and elasticity that may contribute to SGA pregnancies. ${ }^{26}$ Interestingly, uterine vasculature and elasticity changes are nonresponsive to sex-steroid replacement. ${ }^{27}$ In an Ontario-based study of patients diagnosed with malignancy aged $<20$ years $(n=34)$, whole abdominal irradiation was linked to both SGA and premature births. ${ }^{28}$ The association between abdominal irradiation and SGA and premature births was confirmed in two long-term follow-up studies by the National Wilms Tumour Study Group, with incidence proportional to the dose of radiation received..$^{28,29}$ Importantly, whole abdominal irradiation and pelvic irradiation have been repeatedly found to have no association with risk of congenital malformations. ${ }^{28-30}$

Accurate estimation of the risk of premature ovarian damage from a given chemotherapy regimen is extremely difficult. The paucity of long-term data and the different criteria used to categorize ovarian failure, along with the variable lengths of follow-up in reported studies, all hamper the ability to predict risk. Thus, it may be difficult to distinguish between TOF, which eventually resolves, and POF or PM.

Gonadotropin deficiency is one of the few treatable contributors to female infertility following cancer therapy. Cranial irradiation can result in changes to the hypothalamic axis, particularly at high doses ( $>24$ Gy). This high-dose cranial irradiation can result in changes to timing of puberty and delayed menses. Low-dose cranial irradiation can also affect functioning of the hypothalamic axis, causing a slow decline in hormonal levels over time. ${ }^{24}$ This risk is more common in the context of central nervous system tumors (ie, germ-cell tumors, astrocytomas), or in survivors of childhood leukemia who received cranio-spinal irradiation.
In summary, many young female patients may suffer TOF (Figure 1). This is a retrospective diagnosis, made after resumption of ovarian cyclicity, which is usually still accompanied by subtle or more obvious markers of long-term ovarian compromise. If there is no resumption of cyclicity over several years, and endocrine markers show persistently elevated follicle-stimulating hormone levels, then the patient is diagnosed with POF or PM. Most chemotherapy regimens are expected to cause ovarian fragility, which often leads to later-onset premature ovarian failure. Table 1 presents the estimated effect on fertility according to chemotherapy regimen in pediatric and adolescent patients, derived from the published literature and expert clinical opinion.

\section{Assessment of ovarian function}

Assessment of ovarian function and reserve, either before or after cancer treatment, is predominantly based on endocrine parameters. Serum follicle-stimulating hormone reflects function in the more mature follicles, thus is an indicator of current rather than more long-term function. However, there can be marked inter-cycle variability and there is a need to assess levels very early in the follicular phase. Other investigational modalities, including inhibin B levels and biophysical markers such as ovarian volume and antral follicle counts, may also contribute to the overall assessment but are not particularly useful in isolation. ${ }^{31}$ Anti-Müllerian hormone (AMH), which is produced by granulosa cells in the small growing follicles, so reflects the growing follicle pool, has been demonstrated to be a more reliable marker of ovarian reserve, particularly as there is minimal fluctuation over the cycle. ${ }^{32,33}$ However, after an initial decline in AMH associated with chemotherapyinduced follicle damage, recovery of AMH levels can still be demonstrated over time; ${ }^{34}$ as such, pronouncements should not be made about long-term ovarian activity on the basis of single biochemical parameters. Rather, a combination of endocrine and biophysical parameters, assessed over the recovery phase of 12-24 months, may provide the most accurate insight into current and future ovarian potential. ${ }^{35}$

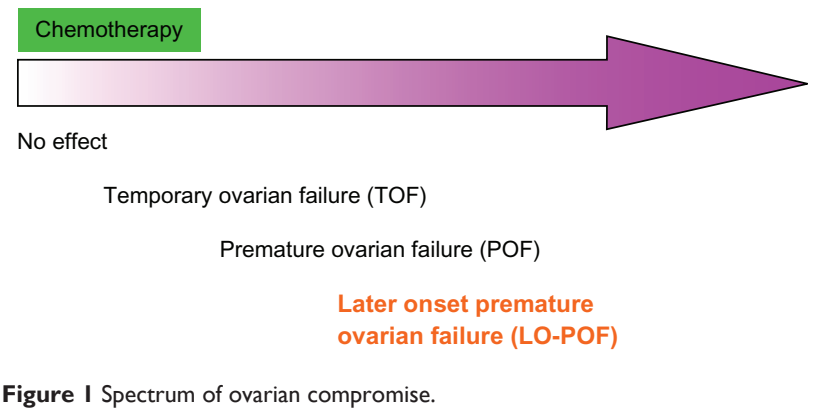


Table I Effect of cancer treatments on fertility according to chemotherapy regimen in female/male pediatric and adolescent patients

\begin{tabular}{|c|c|c|c|}
\hline $\begin{array}{l}\text { Degree of } \\
\text { risk }\end{array}$ & Disease & Protocol cumulative & $\begin{array}{l}\text { Alkylator or platin } \\
\text { dose }\left(\mathrm{g} / \mathrm{m}^{2} \text { or } \mathrm{mg} / \mathrm{m}^{2}\right)\end{array}$ \\
\hline \multicolumn{4}{|l|}{ Female } \\
\hline High risk & $\mathrm{HL}^{\mathrm{CH}}$ & BEACOPP & 7.5 \\
\hline$>80 \%$ risk of permanent & & escBEACOPP & 7.5 \\
\hline \multirow[t]{25}{*}{ A or PM } & & ChIVPP/EVA & \\
\hline & & COPP/ABV $(4 / 6)$ & \\
\hline & & MOPPIABV & \\
\hline & & OEPA/COPP (4) & \\
\hline & $H L^{R T}$ & External beam radiotherapy to a field that includes & \\
\hline & $\mathrm{NHL}{ }^{R T}$ & ovaries & \\
\hline & $\mathrm{NHL}{ }^{\mathrm{CH}}$ & Hyper-CVAD (8) & 14.4 \\
\hline & BMT & Hematopoietic transplant conditioning containing & \\
\hline & & TBI/alkylator or cyclo/busulfan/melphalan & \\
\hline & $\mathrm{BT}^{\mathrm{CH}}$ & SJMB96 (1996-2003) & 16.0 \\
\hline & & & 300.0 \\
\hline & $\mathrm{BT}^{\mathrm{RT}}$ & Cranial radiation $>40 \mathrm{~Gy}$ & \\
\hline & $A L L^{R T}$ & Cranio-spinal irradiation ${ }^{\mathrm{a}}$ & \\
\hline & $\mathrm{OS}^{\mathrm{CH}}$ & MAP & 240.0 \\
\hline & & MAPIE & 27.0 \\
\hline & $\mathrm{ES}^{\mathrm{CH}}$ & EuroEwings 99 VIDE (6)/VAI (8) & 102.0 \\
\hline & & AEWS 003 I interval VDC/IE/VC & $8.4^{c}$ \\
\hline & & & $63^{i}$ \\
\hline & $\mathrm{RMS}^{\mathrm{CH}}$ & IRS III VAC & 23.4 \\
\hline & & IRS IV VAC & 26.4 \\
\hline & & D9803 VAC & 30.8 \\
\hline & & ARST 053I VAC & 16.8 \\
\hline & & ARST 053I VAC/VI & 8.4 \\
\hline & & ARST 043I VDC/IE/Vi & $45.0^{i}$ \\
\hline & & & $9.6^{c}$ \\
\hline \multirow[t]{4}{*}{ Intermediate risk } & $\mathrm{NHL}{ }^{\mathrm{CH}}$ & COP/COPADM/CYVE & 4.8 \\
\hline & & $(+/-R)$ & \\
\hline & $\mathrm{GCT}^{\mathrm{CH}}$ & $\operatorname{BEP}(2 / 4)$ & $200.0 / 400.0$ \\
\hline & ALL ${ }^{C H ~ H R}$ & AALL0232 & 4.0 \\
\hline Low risk & $\mathrm{HL}^{\mathrm{CH}}$ & $A B V D$ & \\
\hline$<20 \%$ risk permanent & & OEPA & \\
\hline \multirow[t]{6}{*}{$\mathrm{A}$ or $\mathrm{PM}$} & & NOVP & \\
\hline & & CHOP & \\
\hline & & COP & \\
\hline & $\mathrm{NHL}^{\mathrm{CH}}$ & COP/COPADM/CYM & 3.3 \\
\hline & & $(+/-\mathrm{R}) \mathrm{RCHOP}$ & \\
\hline & $A L L^{C H S R}$ & AALL033I & 2.0 \\
\hline \multicolumn{4}{|l|}{ Male } \\
\hline High risk** & $\mathrm{HL}^{\mathrm{CH}}$ & BEACOPP & 7.5 \\
\hline \multirow[t]{14}{*}{ Prolonged azoospermia } & & escBEACOPP & 7.5 \\
\hline & & *ChIVPP/EVA & \\
\hline & & *COPP/ABV (4/6) & \\
\hline & & *MOPP/ABV & \\
\hline & & *OEPA/COPP (4) & \\
\hline & $\mathrm{NHL}^{\mathrm{CH}}$ & Hyper-CVAD (8) & 14.4 \\
\hline & $\mathrm{NHL}^{\mathrm{RT}}$ & Testicular radiation dose (men): $>2.5$ Gy & \\
\hline & & Testicular radiation dose (boys): >6 Gy & \\
\hline & BMT & Hematopoietic transplant conditioning containing & \\
\hline & & TBI/alkylator or cyclo/busulfan/melphalan & \\
\hline & $\mathrm{BT}^{\mathrm{CH}}$ & SJMB96 (1996-2003) & 16.0 \\
\hline & & & 300.0 \\
\hline & $B T^{R T}$ & Cranial radiation $>40 \mathrm{~Gy}$ & \\
\hline & $A L L^{R T}$ & Cranio-spinal irradiation ${ }^{\mathrm{a}}$ & \\
\hline
\end{tabular}


Table I(Continued)

\begin{tabular}{|c|c|c|c|}
\hline Degree of risk & Disease & Protocol cumulative & $\begin{array}{l}\text { Alkylator or platin } \\
\text { dose }\left(\mathrm{g} / \mathrm{m}^{2} \text { or } \mathrm{mg} / \mathrm{m}^{2}\right)\end{array}$ \\
\hline & $\mathrm{OS}^{\mathrm{CH}}$ & MAP & 240.0 \\
\hline & & MAPIE & 240.0 \\
\hline & & & $27.0^{\mathrm{i}}$ \\
\hline & $\mathrm{ES}^{\mathrm{CH}}$ & EuroEwings 99 VIDE (6)/VAI (8) & 102.0 \\
\hline & & AEWS 003 I interval VDC/IE/VC & $8.4^{c}$ \\
\hline & & & $63.0^{\circ}$ \\
\hline & $\mathrm{RMS}^{\mathrm{CH}}$ & IRS III VAC & 23.4 \\
\hline & & IRS IV VAC & 26.4 \\
\hline & & D9803 VAC & 30.8 \\
\hline & & ARST 053I VAC & 16.8 \\
\hline & & ARST 053 I VAC/VI & 8.4 \\
\hline & & ARST 043I VDC/IE/Vi & $45.0^{i}$ \\
\hline & & & $9.6^{c}$ \\
\hline \multirow[t]{5}{*}{ Intermediate risk } & $\mathrm{NHL}^{\mathrm{CH}}$ & COP/COPADM/CYVE (+/- R) & 4.8 \\
\hline & $\mathrm{NHL}^{\mathrm{RT}}$ & Abdominal/pelvic radiation (I-6 Gy) with & \\
\hline & & testicular radiation dose as a result of side scatter & \\
\hline & $\mathrm{GCT}^{\mathrm{CH}}$ & $\operatorname{BEP}(2 / 4)$ & $200.0 / 400.0$ \\
\hline & ALL ${ }^{\mathrm{CH} H R}$ & AALL0232 & 4.0 \\
\hline Low risk & $\mathrm{HL}^{\mathrm{CH}}$ & ABVD & \\
\hline Temporary azoospermia & & OEPA & \\
\hline \multirow[t]{8}{*}{ after treatment } & & NOVP & \\
\hline & & $\mathrm{CHOP}$ & \\
\hline & & $\mathrm{COP}$ & \\
\hline & $\mathrm{NHL}^{\mathrm{CH}}$ & COP/COPADM/ CYM (+/- R) & 3.3 \\
\hline & & $\mathrm{RCHOP}$ & \\
\hline & $\mathrm{NHL}^{\mathrm{RT}}$ & Testicular radiation dose: $<0.7 \mathrm{~Gy}$ & \\
\hline & & $\mathrm{RCHOP}$ & \\
\hline & ALL ${ }^{\mathrm{CH} S R}$ & AALL033I & 2.0 \\
\hline
\end{tabular}

Notes: This table is a summary of current research and guidelines on cancer treatments common to childhood and adolescents. Additional factors may need to be taken into account for any individual, particularly if not primary therapy.

Abbreviations: A, amenorrhea; AALL0232/AALL033I/ARST 053I/ARST 043I, AEWS 003I interval VDC/ IE/ VC; to this as it is also a Childrens Oncology Group Protocols Children's Oncology Group Protocols; ABV, doxorubicin, bleomycin, vinblastine; ABVD, doxorubicin, bleomycin, vinblastine, dacarbazine; ALL ${ }^{\mathrm{CH} \text { SR }}$, acute lymphoblastic leukemia standard risk; $A L^{C H} H R$, acute lymphoblastic leukemia high risk; $A L^{C H}$, acute lymphoblastic leukemia; EscBEACOPP: Escalated BEACOPP, bleomycin, etoposide, doxorubicin, cyclophosphamide, vincristine, procarbazine, prednisolone BEACOPP, bleomycin, etoposide, doxorubicin, cyclophosphamide, vincristine, procarbazine, prednisolone; BEP, bleomycin, etoposide, cisplatin; BMT, bone marrow transplant; $\mathrm{BT}^{\mathrm{CH}}$, brain tumor chemotherapy; $\mathrm{BT}^{\mathrm{RT}}$, brain tumor radiotherapy; ChIVPP, chlorambucil, vinblastine, procarbazine, prednisolone; CHOP, cyclophosphamide, doxorubicin, vincristine, prednisolone; COP, cyclophosphamide, vincristine, prednisolone; COPADM, cyclophosphamide, vincristine, prednisolone, doxorubicin, methotrexate; COPP, cyclophosphamide, vincristine, procarbazine, prednisolone; CYVE, cytarabine, etoposide; CYM, cytarabine, methotrexate; $\mathrm{ES}^{\mathrm{CH}}$, Ewing's sarcoma chemotherapy; EuroEwings 99, European Ewing's Sarcoma Protocol; EVA, etoposide, vinblastine, doxorubicin; GCT ${ }^{\mathrm{CH}}$, germ-cell tumor chemotherapy; $\mathrm{HL}^{\mathrm{CH}}$, Hodgkin's lymphoma chemotherapy; HL ${ }^{\mathrm{RT}}$, Hodgkin's lymphoma radiotherapy; Hyper-CVAD, cyclophosphamide, vincristine, doxorubicin, dexamethasone, cytarabine, methotrexate (course A) and cytarabine, methotrexate (course B); MAP, methotrexate, doxorubicin, cisplatin; MAPIE, methotrexate, doxorubicin, cisplatin, ifosfamide, etoposide; MOPP, mechlorethamine, vincristine, procarbazine, prednisolone; $\mathrm{NHL}^{\mathrm{CH}}$, non-Hodgkin's lymphoma chemotherapy; NHL ${ }^{\mathrm{RT}}$, non-Hodgkin's lymphoma radiotherapy; NOVP, mitoxantrone, vincristine, vinblastine, prednisolone; OEPA, vincristine, etoposide, prednisolone, doxorubicin; OS ${ }^{\mathrm{CH}}$, osteosarcoma chemotherapy; PM, premature menopause; R, rituximab; RCHOP, rituximab, cyclophosphamide, vincristine, prednisolone; RMS ${ }^{\mathrm{CH}}$, rhabdomyosarcoma chemotherapy; SJMB03, St Jude Medulloblastoma Protocol; SJMB96, cisplatin, vincristine, cyclophosphamide, autograft; TBI, total body irradiation; VAC, vincristine, actinomycin D, cyclophosphamide; VAI, vincristine, actinomycin D, ifosfamide; VC, vincristine, cyclophosphamide; VDC/IE, vinblastine, doxorubicin, cyclophosphamide, ifosfamide, etoposide (cumulative dose of ifosfamidei, cumulative dose cyclophosphamidec); $\mathrm{Vi}$, vincristine, irinotecan; VIDE, vincristine, ifosfamide, doxorubicin, etoposide; ', ifosfamide dose in $\mathrm{mg} / \mathrm{m}^{2}$; ' , cyclophosphamide dose in $\mathrm{mg} / \mathrm{m}^{2}$.

\section{Options for fertility preservation and ovarian protection in girls and adolescents}

There are a variety of options currently available for girls and young women about to embark on potentially gonadotoxic cancer treatment, including embryo and mature oocyte cryopreservation, ovarian tissue freezing, and ovarian-sparing agents. Recent advances in cryobiology have resulted in different cryopreservation techniques, which clinicians can offer with increasing optimism. ${ }^{36,37}$ However, the risks and expectation of success can vary enormously, and there is no single option that is most appropriate for all young girls and adolescents (see Table 2). Some patients may choose to utilize more than one option for fertility preservation if there is enough time.

Issues to be taken into consideration include the prognosis of the disease, the age and medical condition of the patient, the potential for ovarian tissue involvement by the malignancy, the estimated risk of ovarian damage from the chemotherapy, the medical risks associated with the fertility-preserving technique (including the potential impact of any required hormonal manipulation on estrogen-responsive tumors), as 
Table 2 Comparison of different types of female fertility preservation

\begin{tabular}{llll}
\hline & $\begin{array}{l}\text { Oocyte } \\
\text { freezing }\end{array}$ & $\begin{array}{l}\text { Embryo } \\
\text { freezing }\end{array}$ & $\begin{array}{l}\text { Ovarian tissue } \\
\text { freezing }\end{array}$ \\
\hline $\begin{array}{l}\text { Average number } \\
\text { obtained (range) }\end{array}$ & $14.6(3-45)$ & $6.8(3-15)$ & I40 (28-538) \\
$\begin{array}{l}\text { Invasiveness } \\
\text { Time required }\end{array}$ & $\begin{array}{l}\text { Minimal } \\
\text { 2+ weeks }\end{array}$ & $\begin{array}{l}\text { Minimal } \\
\text { 2+ weeks }\end{array}$ & $\begin{array}{l}\text { Moderate } \\
\text { I day }\end{array}$ \\
$\begin{array}{l}\text { Expectation of } \\
\text { success }\end{array}$ & $\begin{array}{l}\text { Moderate (if } \\
\text { enough oocytes) }\end{array}$ & Excellent & Low (currently) \\
\hline
\end{tabular}

Note: This table is a summary of outcomes derived from an audit of the Melbourne IVF fertility preservation database, 2000-20I2.

well as the magnitude of expected additional fertility benefit and the required delay before commencement of cancer treatment.

It is of paramount importance that girls and their families have the opportunity to discuss with a fertility medicine specialist about the options available. Even if no preserving techniques are possible, this initial contact establishes a pathway for subsequent fertility evaluation and care, which is of great importance and will continue often for many years after the cancer treatment is completed.

\section{Embryo cryopreservation}

Embryo cryopreservation is the most established technique for preservation of fertility, and is a routinely practiced part of all in vitro fertilization programs. Unfortunately, it is not a useful option for prepubertal girls because of the immaturity of the hypothalamic-pituitary-ovarian axis. There are also several other factors that hamper its applicability for young female cancer patients. The process involves 10-14 days of hormone stimulation in order to grow multiple follicles and maximize oocyte yield, and this time delay may be detrimental for some young women, especially those with rapidly progressive hematological malignancies. Additionally, there is a requirement for a partner's or donor's sperm, which can have profound subsequent ethical and legal implications and which precludes applicability for girls and very young women. Until recently, embryo cryopreservation was associated with higher survival rates than oocyte cryopreservation, but with newer techniques such as vitrification resulting in excellent oocyte survival rates, there is now no need to freeze embryos just to maximize gamete survival. ${ }^{37,38}$

\section{Oocyte cryopreservation}

As with embryo cryopreservation, the requirement for a mature hypothalamic-pituitary-ovarian axis precludes the applicability of ovarian stimulation and oocyte cryopreservation for prepubertal girls. However, for postmenarchal girls and adolescents, in situations where there is enough time, this may be a viable option, particularly as it maintains autonomy with no need for a male partner.

The hormonal stimulation required to develop multiple follicles is associated with elevation in estrogen and there is a small risk of over-response and thus development of severe ovarian hyperstimulation syndrome (OHSS). There is no data describing the magnitude of risk of severe OHSS in young female cancer patients, but in the infertile population, the risk is increased in women with polycystic ovarian syndrome and in young women, so careful and judicious use of stimulation is required. Recently, it has been demonstrated that use of a gonadotropin-releasing hormone agonist $(\mathrm{GnRH}-\mathrm{a})$ to trigger final follicle maturation and ovulation may dramatically reduce the risk of OHSS in vulnerable situations. ${ }^{39}$

With oocyte survival of over $70 \%-80 \%$ after thawing reported with slow-freezing protocols, recent reports of over $90 \%$ survival with vitrification, and subsequent excellent fertilization rates demonstrated, oocyte cryopreservation may provide multiple opportunities to later conceive, provided enough oocytes (ie, 10-20) are retrieved. ${ }^{38}$

It is also possible to aspirate immature oocytes after minimal stimulation, then to mature them in vitro prior to cryopreservation. ${ }^{40}$ While this is still an evolving technique, there are potential advantages for young cancer patients, including the reduced time and stimulation requirement, and the reduced risk of OHSS.

\section{Ovarian tissue cryopreservation}

Ovarian tissue harvesting and subsequent autotransplantation, although not yet considered as an established and routine procedure, has developed into a highly promising strategy for young girls about to embark on cancer treatment, many of whom would have no alternative fertility preservation option available to them otherwise. ${ }^{41}$

The harvesting procedure involves a laparoscopic technique ${ }^{42}$ to remove a cortical segment of ovary or a whole ovary, depending on the estimated risk of subsequent sterility from chemoradiation. ${ }^{43}$ The ovarian tissue is sliced up into cortical strips and subsequently cryopreserved. ${ }^{44}$

Grafting of ovarian tissue back into the patient requires another laparoscopic procedure, with strips inserted into various orthotopic locations, including the remaining ovary and pelvic side walls and even heterotopic sites, ${ }^{45}$ with recovery of ovarian function demonstrated some months after the procedure. ${ }^{46}$ 
Reports of 28 births have been published after ovarian tissue grafting, conceived both spontaneously and with in vitro fertilization. ${ }^{47-53}$ However, follicular development from grafted ovarian tissue does not always follow typical cyclical patterns and it is in fact often quite problematic to obtain good quality oocytes. Ischemic damage to follicles and stroma contribute to this difficulty. ${ }^{45}$ The duration of function of grafted ovarian tissue is finite, lasting on average several years, ${ }^{48}$ depending on the size of the slices and the volume grafted, hence sometimes more than one grafting procedure may be required. Thus, most commonly, tissue is grafted at the time when fertility is required. However, some young women may choose to have tissue grafted purely to provide restoration of endocrine function. ${ }^{54}$

The major advantages of this technique include the ability to obtain ovarian tissue with large numbers of ovarian follicles, even in young girls, and the immediacy of the harvesting procedure, which does not require a delay in cancer treatment commencement. However, a laparoscopic technique is currently required and there are well-documented risks, both anesthetic and surgical, ${ }^{42}$ which may be increased in young, unwell cancer patients, particularly those with respiratory or hematological compromise.

Despite rigorous and repeated testing of harvested tissue by histological, immunohistochemical, and molecular techniques, concern remains that autotransplantation may carry a risk of the reintroduction of malignant cells, particularly in the acute leukemias. ${ }^{55,56}$ However, to date, there are no reported cases of contamination causing cancer recurrence in the clinical setting. ${ }^{57-59}$

Whole- and hemi-ovary cryopreservation and microvascular transplantation have been demonstrated successfully in sheep ${ }^{60}$ and a single birth has been reported after microsurgical transplantation of a whole fresh ovary into an identical twin by Silber, ${ }^{52}$ but technical difficulties have so far precluded this from being utilized in the routine clinical setting. ${ }^{61}$

Given the recent improvements with freezing, grafting, and stimulation approaches, and the demonstration of live births unequivocally related to autotransplantation, ${ }^{47}$ we can be increasingly optimistic about the value of ovarian tissue cryopreservation as a genuinely useful strategy for fertility preservation in girls at significant risk of sterility from their cancer treatment.

\section{In vitro culture of ovarian follicles}

Another promising technique, currently still at the experimental stage, is in vitro culture of ovarian tissue and ovarian follicles. Several groups have now demonstrated that it is possible to isolate small follicles from fresh or cultured ovarian tissue, which are then subjected to longterm culture until they reach antral follicle stage, at which point oocytes are extracted and matured in vitro, before fertilization..$^{62,63}$

The potential advantages of in vitro culture include reducing the risk of malignant cell reintroduction with grafting and avoiding both a laparoscopic procedure and the need for ovarian stimulation.

\section{Ovarian protection during cancer treatment}

It is conceptually very appealing and may be possible to reduce the gonadotoxic effects of chemotherapy and radiotherapy in postpubertal girls and young women with nonsurgical modalities, such as gonadotropin-releasing hormone $(\mathrm{GnRH})$ analogs and immunomodulation.

GnRH analogs are widely used in gynecological and reproductive medicine settings. They act on the pituitary to suppress gonadotropin secretion, inducing a quiescent state of non-cyclicity. The exact mechanism of protective action during chemotherapy is still unclear but may be mediated through reduction of blood flow to the ovary, modulation of AMH activity, or interruption of the accelerated recruitment of follicles during damaging chemotherapy. ${ }^{64}$

Initial animal studies have demonstrated a substantial protective effect on follicle numbers after chemotherapy. ${ }^{65}$ Subsequently, many clinical studies have been reported (Table 3), including several randomized controlled trials and meta-analyses evaluating GnRH agonists for ovarian protection $^{64,66-69}$ but results are contradictory, perhaps because of the different cancer treatments, disparate follow-up periods, and different modalities used for assessment of ovarian function. Given the controversy, however, it is recommended that all patients considered for this therapy be advised that benefit has not been conclusively demonstrated.

Other forms of ovarian protection have also been evaluated in a research setting, including the use of the nontoxic immunomodulator AS101, which was found to protect the follicle pool after exposure to cyclophosphamide in a rodent model. ${ }^{70}$

A recent publication has elegantly demonstrated the molecular mechanisms of DNA damage-induced apoptosis in primordial follicle oocytes. ${ }^{71}$ The authors also demonstrated that the immature murine oocyte can survive DNA damage and produce live offspring when protected from death by loss of the pro-apoptotic protein p53-upregulated modulator 
Table 3 Summary of studies in which ovarian function was assessed after chemotherapy treatment administered with or without gonadotropin-releasing hormone-analog $(\mathrm{GnRH}-\mathrm{a})$

\begin{tabular}{|c|c|c|c|c|c|}
\hline \multirow[t]{2}{*}{ Study or subgroup } & \multicolumn{2}{|c|}{$\begin{array}{l}\text { Ovarian function protected*, } \\
\text { N (\%) }\end{array}$} & \multirow[t]{2}{*}{ Outcome } & \multicolumn{2}{|c|}{$\begin{array}{l}\text { Prospective }(P) \text { or } \\
\text { retrospective }(R)\end{array}$} \\
\hline & GnRH-a & Control & & $\begin{array}{l}\text { GnRH-a } \\
\text { group }\end{array}$ & $\begin{array}{l}\text { Control } \\
\text { group }\end{array}$ \\
\hline Waxman et al ${ }^{154}$ & $4(50)$ & $3(33)$ & NS & $P$ & $P$ \\
\hline $\begin{array}{l}\text { Pereyra Pacheco } \\
\text { et al }{ }^{155}\end{array}$ & $12(100)$ & 0 & Favors GnRH & $P$ & $\mathrm{R}$ \\
\hline $\begin{array}{l}\text { Blumenfeld and } \\
\text { Eckman }{ }^{156}\end{array}$ & $70(93)$ & $38(46)$ & $\begin{array}{l}\text { Favors GnRH } \\
(P<0.0 I)\end{array}$ & $P, R$ & $P$ \\
\hline Dann et al ${ }^{157}$ & $7(100)$ & $5(83)$ & NS & $P$ & $\mathrm{P}$ \\
\hline Somers et al ${ }^{158}$ & $19(95)$ & $14(70)$ & $\begin{array}{l}\text { Favors GnRH } \\
(P<0.04)\end{array}$ & $\mathrm{P}$ & Not stated \\
\hline Giuseppe et al ${ }^{159}$ & $14(100)$ & $8(53)$ & Favors GnRH & $P$ & $P$ \\
\hline Badawy et al 160 & $35(90)$ & $13(33)$ & $\begin{array}{l}\text { Favors GnRH } \\
(P<0.00 \mathrm{I})\end{array}$ & $P$ & $P$ \\
\hline $\begin{array}{l}\text { Blumenfeld } \\
\text { and von Wolff'161 }\end{array}$ & $63(97)$ & $29(63)$ & $\begin{array}{l}\text { Favors GnRH } \\
(P<0.00 \mathrm{I})\end{array}$ & $P$ & $P$ \\
\hline $\begin{array}{l}\text { Sverrisdottir } \\
\text { et al }{ }^{162}\end{array}$ & $8(36)$ & $2(10)$ & NS $(P=0.07 I)$ & $P$ & $P$ \\
\hline Gerber et $\mathrm{al}^{163}$ & $21(70)$ & $17(57)$ & $\mathrm{NS}(P=0.284)$ & $P$ & $P$ \\
\hline
\end{tabular}

Notes: *Incongruent follow-up periods and different modalities were used to assess ovarian function; these included: endocrine assessments (follicle-stimulating hormone, luteinizing hormone, estradiol, progesterone, anti-Müllerian hormone, inhibin A and B), sonography, regular menstruation, and conception.

Abbreviation: NS, no significant difference between groups.

of apoptosis. The importance of this finding is that blockade of p53-upregulated modulator of apoptosis may conceivably protect fertility during cancer therapy and prevent POF ${ }^{71}$ as such, this work paves the way for development of new strategies for ovarian protection.

\section{Transposition of the ovaries prior to radiotherapy}

Oophoropexy may be performed prior to pelvic radiotherapy, either by laparoscopy or laparotomy, with transposition of the ovaries outside the field of radiation, most commonly for treatment of cervical cancer or pelvic sarcoma. ${ }^{72}$ The success of the procedure will be affected by the dose of radiation, the use of ovarian shielding, the extent of scatter radiation, and, most importantly, the degree of vascular compromise. There is great variation in the reduction of risk by ovarian transposition; thus, there is no consensus that this technique, with its necessity for laparoscopy, should be performed in the setting of pelvic cancer. ${ }^{73}$

\section{Common cancer treatments and infertility risk in males}

The prepubertal testis is highly susceptible to the toxic effect of chemotherapy and irradiation due to the constant turnover of its undifferentiated spermatogonia. ${ }^{73-75}$
Low-dose chemotherapy or irradiation can deplete the rapidly dividing and differentiating spermatogonia in the postpubertal testis, while less sensitive, slow dividing cells - such as the quiescent spermatogonial stem cells, spermatocytes, and spermatids - survive. ${ }^{76}$ After such cytotoxic insult, the surviving stem cells turn into mitotically active spermatogonia. Together with the supporting Sertoli cells (which are more resilient to chemotherapy and irradiation), surviving stem cells become the foundation of spermatogenesis regeneration. ${ }^{77}$

If testicular damage is severe due to high-dose chemotherapy/ irradiation, all subpopulations of spermatogonial stem cells will commit to apoptosis. In a severe cytotoxic insult scenario, Sertoli cells will be significantly damaged and lose their ability to support spermatogenesis. ${ }^{77}$ The clinical outcome in these cases will be permanent sterility.

Bone marrow transplantation, which requires conditioning with high-dose chemotherapy/high-dose irradiation, is associated with a high risk of future infertility. 78,79

As Leydig cells are relatively resistant to chemotherapy/ irradiation insults, androgen deficiency requiring testosterone replacement is rare, even in the setting of severe oligospermia or azoospermia. ${ }^{20}$ Doses as high as 12 Gy are required to impair pubertal development and doses of 20-30 Gy are required to cause hypogonadism, which indicates a need for 
androgen replacement. ${ }^{80-82}$ Relative androgen deficiency and gynecomastia have been reported in patients treated with mechlorethamine, vincristine, procarbazine, and prednisone (MOPP) or high-dose cyclophosphamide. ${ }^{83,84}$

The effect of chemotherapy on the pre- and postpubertal testis, and hence future fertility, varies and is mainly agent and dose dependent. ${ }^{85,86}$ The potential gonadotoxic impact is also associated with the fractionation schedule of the treatment. Receiving multiple administrations of low-dose chemotherapy might have more detrimental effects than exposure to higher dosages delivered in fewer administrations. ${ }^{87}$

Alkylating agents and platinums seem to have the most profound reproductive effects. The reported threshold for future infertility in prepubertal patients for cyclophosphamide ranges between $7.5-9.0 \mathrm{~g} / \mathrm{m}^{2} 82,88,89$ and $10.0 \mathrm{~g} / \mathrm{m}^{2}(300 \mathrm{mg} / \mathrm{kg})$ in postpubertal patients. ${ }^{90}$ It is believed that spermatogenesis recovery is unlikely from doses of $19 \mathrm{~g} / \mathrm{m}^{2} .{ }^{91}$ Future infertilityassociated threshold doses for other alkylating agents and platinums have been reported. ${ }^{92}$ Reports on the commonly used multi-agent chemotherapy regimens (MOPP and cyclophosphamide, vincristine, procarbazine, prednisolone [COPP]) showed high rates of long-term azoospermia $(85 \%-100 \%)^{93}$ with a clear dose-dependent effect seen in cyclophosphamide-based regimens. ${ }^{75,88,94}$ Antimetabolites, vinca alkaloids, and topoisomerase inhibitors have been shown to be gonadotoxic, however with less detrimental effect. ${ }^{95,96}$

The extent of DNA damage to testicular germ cells and somatic cells is field, dose, and fractionation dependent. ${ }^{80,97,98}$ Spermatogenesis is highly sensitive to radiation doses as low as $0.1 \mathrm{~Gy} .{ }^{99}$ Reversible short-term azoospermia has been identified at the dose of $0.35 \mathrm{~Gy},{ }^{98}$ while doses of 2-3 Gy may cause a long-term effect with the potential for recovery. ${ }^{99}$ Doses of more than 6 Gy are able to cause total depletion of spermatogonial stem cells and permanent sterility. ${ }^{86,99}$

Conditioning regimens for bone marrow transplantation involving TBI (10 or $13 \mathrm{~Gy}$ ) have been reported to be highly associated with spermatogenesis failure, with an azoospermia rate of $85 \% .^{100}$

\section{Options for fertility preservation in boys and adolescents}

Given the potential detrimental effects of chemotherapy and/or radiation therapy on future fertility, preservation options should be discussed with patients and their families prior to the initiation of any therapy.

Provided a semen sample can be produced, the fertility of adolescent boys facing chemotherapy/radiotherapy can be preserved with a similar success rate to that achieved in adults. Pubertal boys with a testicular volume of 10-12 mL should be encouraged to produce a sample. ${ }^{101,102}$ Boys at the onset of puberty may have small numbers of sperm cryopreserved after testicular biopsy or aspiration under anesthesia. Intracytoplasmic sperm injection may then result in their ability to father a child, but electroejaculation equipment sizes may preclude its use in young adolescents. Some patients may be unfamiliar with masturbation and others unable to ejaculate for various other reasons (social, religious/cultural, or medical). For them, sperm can be retrieved by penile vibratory stimulation, electroejaculation, or surgically from the epididymis or the testis. Unfortunately, some patients may present initially with oligospermia or even azoospermia. This may be related to the stress effect of the disease on spermatogenesis, possibly mediated through proinflammatory cytokines. ${ }^{103}$ This phenomenon is frequent in patients with advanced-stage Hodgkin's lymphoma. ${ }^{104}$

Sperm cryopreservation or sperm banking is a routinely used, highly reliable, and well-established approach ${ }^{102,105,106}$ applicable to adolescents but unfortunately not to prepubertal boys.

As prepubertal boys cannot benefit from sperm banking, alternative strategies have been developed but all are currently experimental. These strategies are based on the cryopreservation of immature spermatogenic cells as cell suspensions or whole testicular tissue for future fertility restoration. ${ }^{92}$

Cell-suspension freezing protocols, achieving $60 \%$ postthaw viability, have been reported. ${ }^{107,108}$

Testicular tissue-freezing protocols enabling the maintenance of cell-to-cell contacts and the preservation of the stem cell niche have been developed. Together, the use of dimethyl sulfoxide (DMSO) as cryoprotectant, ${ }^{109}$ slow-programmed freezing, ${ }^{110}$ and the addition of sucrose ${ }^{92}$ have been shown to better preserve tissue structure, protect spermatogonial morphology, and reduce germ cell and Sertoli cell loss during freezing-thawing, respectively.

Three main strategies for the use of spermatogonial stem cells are under ongoing investigation:

1. In vitro generation of spermatozoa from harvested spermatogonia using artificial supporting environment. A successful proliferation and differentiation of diploid mice germ cells up to completion of spermatogenesis in a three-dimensional cell culture system has been recently described. ${ }^{111}$ More recently, an in vitro production of functional sperm cells from neonatal mouse testis tissue was reported. These cells were successfully used 
to produce a healthy, fertile offspring. ${ }^{112}$ Further research is required to investigate potential epigenetic changes and their long-term implications on future generations.

2. Infusion of germ-cell suspension into the testis, using the "host" somatic structures and their secreted factors as the supportive microenvironment of further spermatogenesis. Ultrasound-guided infusion of germ-cell suspensions via the rete testis offers a noninvasive approach to autologous infusion of harvested germ cells. Although this strategy seems promising, major safety concerns regarding the potential risk of tumor cell reintroduction leading to disease relapse must be addressed before this technique can be considered for clinical use. Cell-sorting techniques are under ongoing investigation. ${ }^{113,114}$

3. Immature testicular tissue grafting. Although no reports of successful testicular autografting in men have been published as yet, experiments on primates have revealed the principal application of this approach. ${ }^{115}$ "Xenografting," grafting into a different organism, has also been investigated as a possible therapeutic approach. Essentially, after completion of differentiation and spermiation, sperm can be retrieved and used for intracytoplasmic sperm injection. So far, experiments involving the xenografting of human prepubertal cryopreserved testicular tissue into immunodeficient mice have not yet demonstrated complete spermatogenesis up to spermatid stage. ${ }^{116,117}$

More research is needed to establish the best approach to generating spermatozoa from immature stem cells via in vivo or in vitro maturation. In the meantime, prepubertal tissue preservation should be discussed with boys and their parents and samples should be banked only after careful counseling that emphasizes the experimental nature of this approach.

\section{Ethical issues in fertility preservation}

Amid rapid progress in technologies, a number of clinical guidelines have been published to aid health care professionals and institutions in providing appropriate information and fertility preservation options to patients and families, several of which cover pediatric and adolescent patients specifically. ${ }^{118-120}$ However, guidelines are only recommendations; they are not legally binding nor accompanied by funding mechanisms, resource accessibility, or educational programs. Neither is their uptake routinely evaluated. Even within the relatively wellresourced, centralized world of pediatric oncology, many barriers to optimal fertility management persist. Discussion regarding fertility may be variable, with a lack of consistency in the information provided, and the uptake of fertility preservation options remains low. ${ }^{121-123}$ Older adolescent patients, who fall outside the pediatric realm, suffer a unique spectrum of individually rare tumors and are spread thinly across the adult health system, rendering them even more disadvantaged in terms of both utilizing the window of opportunity for fertility preservation, and in the long-term follow-up of their reproductive potential.

\section{Addressing patient and family needs}

Research into the long-term psychological effects of cancer-related infertility in young people with childhood or adolescent cancer is largely limited to retrospective survey and qualitative studies. Such research strongly suggests that awareness and understanding of childhood and adolescent cancer-related fertility issues among survivors is low, ${ }^{124,125}$ despite demonstration of a strong desire for parenthood in cancer survivors. ${ }^{126,127}$ It has been demonstrated that uncertainty about fertility status has caused worry about the future in young adult males ${ }^{128}$ and Saito et $\mathrm{al}^{129}$ describe sperm banking as being a protective factor in the emotional battle against cancer. Beyond the issue of childbearing itself, ${ }^{130}$ a qualitative study of 38 survivors of teenage cancer, examining the effect of fertility issues on transition to adulthood and survivorship, has acknowledged the broader representation of fertility as a social value and infertility as a stigma. The study describes four threads of experience over time: (1) prioritizing normality and marginalizing fertility, (2) fertility concerns compromising attempts at normality, (3) ongoing impairments to health that mediate fertility matters, and (4) fertility concerns dominating the cancer legacy. Both Crawshaw and Sloper ${ }^{130}$ and Wilkes et $\mathrm{al}^{131}$ suggest that the relative that the relative importance of fertility concerns can shift between contexts and over time; suggest that fertility is linked to sexual, personal, and social identity; and implore clinicians to pay proactive and reactive attention to fertility-related issues longitudinally over the cancer journey to promote resilience. Reproductive counseling is also required to support difficult decisionmaking for survivors who may experience more distress when contemplating failure of assisted reproductive technologies, eligibility for adoption, concerns around health and risk of recurrence, and the potential transmission of cancer to their offspring. ${ }^{132-134}$

Many adolescent survivors cannot recall receiving fertility information at diagnosis. ${ }^{135}$ In a survey of parents 
of both children and adolescents with cancer, fewer than $30 \%$ felt they had received adequate information. ${ }^{136}$ Despite widely held beliefs that young patients and families are too emotionally saturated to receive detailed fertility information, studies show that they do want such information and opportunities for fertility preservation at diagnosis. ${ }^{136-138}$ There is also a paucity of validated tools to empirically assess child, parent, and adolescent needs and concerns in this area. The development of such tools will prove time consuming and difficult given that overall numbers are small and age and gender differentiations are important. ${ }^{139}$ However, in the future, this may be aided by multidisciplinary networks/ consortia such as the Oncofertility Consortium.

\section{Decision-making and ethical concerns}

Supporting the high-stake decision-making for families, about fertility concerns, during the time-critical period of severe cognitive and emotional strain at diagnosis, is imperative and requires staged discussions. ${ }^{140}$ An approach involving multiple providers can mean that patients and families experience confusion and loss of coordination. ${ }^{141}$ Gardino et al ${ }^{142}$ speak of several systematic ways a multidisciplinary team can best manage the fertility preservation process. A patient navigator or advocate can help assimilate the information provided and facilitate decision-making; ${ }^{143}$ however, if there is good collaboration and communication between oncologists and reproductive medicine specialists, then this additional level of assistance may not be necessary.

Utilizing internet resources can further add to support provided by the clinician to the family, and aid in decision making pathways (http://www.myoncofertility.org). ${ }^{144}$ Alternatively, a simple decision tree to pictorially describe separate options, decision points, consequences, and final outcomes, can provide a logical interactive platform for systematic discussion useful to health care providers, adolescent patients, and families. ${ }^{145,146}$

In practical terms, for children and adolescents under 18 years, parents are usually the "surrogate" decision-makers in the consent process for fertility preservation procedures. However, it is the responsibility of team to inform and involve the young person to the level of their capacity. ${ }^{147}$ If they are not up to assent, then health care professionals and family should act in the child's best interests. ${ }^{148}$ The assessment of whether a child is capable of assent may require independent expertise. A review on decision-making about fertility in AYAs suggests that adolescents have three main desires: information about the potential impact of cancer treatment on fertility, information about fertility preservation options, and participation in decision-making. Further research is required to explore decision-making roles in children and adolescents with cancer. ${ }^{137}$

Fertility preservation procedures such as gonadal tissue cryopreservation for children and adolescents are best termed “experimental therapeutic research.” While the potential risks and benefits are not wholly known, unless the techniques are offered, the opportunity to evaluate these procedures and assess for clinical benefit will be missed. It is recommended that they should only be performed in centers in which the necessary expertise is available with the support of an appropriate code of practice.

There should also be systematic long-term follow-up so that the many unanswered questions, including those concerning the best options for fertility preservation for prepubertal patients, may be addressed over the long-term. ${ }^{73,149,150}$ Valid consent renders potentially harmful interventions both ethically and legally appropriate, but requires the decision-maker to be informed, competent, and acting voluntarily. These conditions may be compromised in the face of a family's distress around a child's cancer diagnosis, and having to consider future childbearing for a child with a life-threatening illness under time constraints. ${ }^{151}$ Posthumous parenting issues can be addressed by detailing precise instructions in a legal consent document. This will reduce but not obviate the need for legal intervention to determine ownership of tissue in case of the young person's death. For patients, a two-stage process may be appropriate, whereby initially consent for tissue storage is sought, then subsequent consent for the use of tissue is sought at a time when the young person is able to comprehend the issues fully and express detailed preferences. ${ }^{152}$

Specific ethical difficulties may arise when there is conflict among family members. For example, some parents may not want to inform the young person about fertility concerns, or a male adolescent may be unwilling to consent to sperm banking or retrieval while this is the preferred parental option. These situations require thoughtful handling with a team-based approach, often involving a child advocate or clinical ethics team.

Broader ethical concerns may relate to issues of prognosis and cost. Is it right to impart information and offer interventions to patients who have neither prospect of affording them nor a substantial chance of reaping the future benefit? In reality, not all options are available to all patients. Currently, the majority of insurance companies in the USA do not cover fertility preservation procedures for newly diagnosed cancer patients. ${ }^{153}$ Even subsidized health 
care systems provide limited funding for fertility preservation procedures before a diagnosis of infertility can technically be made, even though it may be reliably anticipated. However, the right for patients and families to be informed and act as decision-makers with appropriate guidance is a right that transcends prognosis or income.

Comprehensive models of care can offer a solution to help bridge the gap between recommendations for best-practice fertility management and current practices in oncology. This requires collaboration between researchers, clinicians, and advocacy groups to address issues of education, access, funding, and research to support the emergence of oncofertility as a discipline in its own right. International advances are being made in this regard that may guide future development in this field.

\section{Conclusion: the way forward}

While there is now general agreement as to the importance of addressing the fertility implications of cancer treatment, in practice there are many challenges facing physicians. Informing a family about the diagnosis of a potentially life-threatening cancer is usually associated with enormous trauma and emotion. For major cancer centers, integration with a reproductive medicine unit that provides fertility preservation advice and services and, for smaller units, online resources and telephone counseling for physicians and patients and their families, with access to regional reproductive medicine centers, will ensure that fertility concerns are appropriately addressed in a timely fashion.

Establishment of rigorous long-term late effects and follow-up services with regular monitoring of reproductive function and counseling about further options will ensure that young patients are not lost in the system at a critical time of loss of reproductive potential.

In the case of female patients, large international databases allowing access to information about long-term assessment of ovarian reserve, endocrinologically and biophysically, will greatly enhance our understanding about the short- and longerterm ovarian responses to insults such as chemotherapy. Further advances in mechanisms of ovarian protection during cancer treatment may, in some cases, reduce the reliance on procedural methods. Increasing worldwide experience, shared in a collaborative fashion, and escalating births, will also facilitate the progression of the more experimental options including ovarian tissue and whole-ovary grafting, into the realms of routinely offered clinical options, providing rates of success and procedural ease that far outweigh the risks.

In addition, financial assistance packages and subsidized care would ensure that all patients could be given the opportunity to avail themselves of options.
There is now increasing recognition within the medical community of the importance of fertility for young cancer survivors. Although many challenges remain, with recent advancements in the clinical applicability of fertility preservation options, and with improving collaboration between oncologists and reproductive medicine specialists, we can now strive to maximize accessibility to useful oncofertility services for all young cancer patients and their families.

\section{Disclosure}

The authors declare no conflicts of interest in this work.

\section{References}

1. Siegel R, DeSantis C, Virgo K, et al. Cancer treatment and survivorship statistics, 2012. CA Cancer J Clin. 2012;62(4):220-241.

2. American Cancer Society. Cancer treatment and survivorship facts and figures [web page on the Internet]. Atlanta, GA: American Cancer Society; nd. Available from: http://www.cancer.org/research/ cancerfactsfigures/cancertreatmentsurvivorshipfactsfigures/index. Accessed April 6, 2013

3. Cancer (AIHW) [homepage on the Internet]. Australian Institute of Health and Welfare, Australian Cancer Database, 2013. Available from: http://www.aihw.gov.au/cancer-data/.

4. Ferlay J, Shin HR, Bray F, Forman D, Mathers C, Parkin DM. Globocan 2008: cancer incidence and mortality worldwide: IARC Cancerbase No 10 [data on the Internet]. Lyon: International Agency for Research on Cancer; 2010. Available from: http://globocan.iarc.fr. Accessed April 11, 2011.

5. Thursfield V, Farrugia H, Karahalios E, Giles G. Cancer Survival Victoria 2012: Estimates of survival in 2006-2010 (and comparisons with earlier periods). Melbourne, Australia; Cancer Council Victoria; 2012. Available from: http://www.cancervic.org.au/downloads/cec/ cancer-survival-victoria-2012.pdf. Accessed April 11, 2011.

6. Pui CH, Gajjar AJ, Kane JR, Qaddoumi IA, Pappo AS. Medscape. Challenging issues in pediatric oncology. Nat Rev Clin Oncol. 2011; 8(9):540-549.

7. Hansen KR, Knowlton NS, Thyer AC, Charleston JS, Soules MR, Klein NA. A new model of reproductive aging: the decline in ovarian non-growing follicle number from birth to menopause. Hum Reprod. 2008;23(3):699-708.

8. Wallace WH, Kelsey TW. Human ovarian reserve from conception to the menopause. PLoS One. 2010;55(1):e8772.

9. Anderson RA, Themmen AP, Al-Qahtani A, Groome NP, Cameron DA. The effects of chemotherapy and long-term gonadotrophin suppression on the ovarian reserve in premenopausal women with breast cancer. Hum Reprod. 2006;21(10):2583-2592.

10. Levine J, Canada A, Stern CJ. Fertility preservation in adolescents and young adults with cancer. J Clin Oncol. 2010;28(32):4831-4841.

11. Anderson RA, Wallace WH. Fertility preservation in girls and young women. Clin Endocrinol (Oxf). 2011;75(4):409-419.

12. Meirow D, Biederman H, Anderson RA, Wallace WH. Toxicity of chemotherapy and radiation on female reproduction. Clin Obstet Gynecol. 2010;53(4):727-739.

13. Meirow D, Dor J, Kaufman B, et al. Cortical fibrosis and blood-vessels damage in human ovaries exposed to chemotherapy. Potential mechanisms of ovarian injury. Hum Reprod. 2007;22(6):1626-1633.

14. Whitehead E, Shalet SM, Blackledge G, Todd I, Crowther D, Beardwell CG. The effect of combination chemotherapy on ovarian function in women treated for Hodgkin's disease. Cancer. 1983;52(6): 988-993. 
15. Youlden D, Baade P, Ward L, et al. Childhood Cancer Incidence in Australia, 1983-2006. Brisbane: Viertel Centre for Research in Cancer Control, Cancer Council Queensland, and Australian Paediatric Cancer Registry; 2009. Available from: http://www.cancerqld.org.au/icms_ docs/60370_Childhood_cancer_incidence_in_Australia_1983_-_2006. pdf. Accessed April 11, 2013.

16. De Bruin ML, Huisbrink J, Hauptmann M, et al. Treatment-related risk factors for premature menopause following Hodgkin lymphoma. Blood. 2008;111(1):101-108.

17. Thomson AB, Critchley HO, Kelnar CJ, Wallace WH. Late reproductive sequelae following treatment of childhood cancer and options for fertility preservation. Best Pract Res Clin Endocrinol Metab. 2002; 16(2):311-334.

18. Wallace HB, Thomson AB, Kelsey TW. The radiosensitivity of the human oocyte. Hum Reprod. 2003;18(1):117-121.

19. Wallace WH, Thomson AB, Saran F, Kelsey TW. Predicting age of ovarian failure after radiation to a field that includes the ovaries. Int $J$ Radiat Oncol Biol Phys. 2005;62(3):738-744.

20. Sklar C. Reproductive physiology and treatment-related loss of sex hormone production. Med Pediatr Oncol. 1999;33(1):2-8.

21. Lushbaugh CC, Casarett GW. The effects of gonadal irradiation in clinical radiation therapy: a review. Cancer. 1976;37(Suppl 2):1111-1125.

22. Sanders JE, Hawley J, Levy W, et al. Pregnancies following highdose cyclophosphamide with or without high-dose busulfan or total-body irradiation and bone marrow transplantation. Blood. 1996; 87(7):3045-3052.

23. Wallace WH, Shalet SM, Crowne EC, Morris-Jones PH, Gattamaneni HR. Ovarian failure following abdominal irradiation in childhood: natural history and prognosis. Clin Oncol (R Coll Radiol). 1989;1(2):75-79.

24. Bath LE, Critchley HO, Chambers SE, Anderson RA, Kelnar CJ, Wallace WH. Ovarian and uterine characteristics after total body irradiation in childhood and adolescence: response to sex steroid replacement. Br J Obstet Gynaecol. 1999;106(12):1265-1272.

25. Chiarelli AM, Marrett LD, Darlington GA. Pregnancy outcomes in females after treatment for childhood cancer. Epidemiology. 2000;11(2): $161-166$.

26. Critchley HO, Wallace WH, Shalet SM, Mamtora H, Higginson J, Anderson DC. Abdominal irradiation in childhood; the potential for pregnancy. Br J Obstet Gynaecol. 1992;99(5):392-394.

27. Holm K, Nysom K, Brocks V, Hertz H, Jacobsen N, Müller J. Ultrasound B-mode changes in the uterus and ovaries and Doppler changes in the uterus after total body irradiation and allogeneic bone marrow transplantation in childhood. Bone Marrow Transplant. 1999; 23(3):259-263.

28. Green DM, Peabody EM, Nan B, Peterson S, Kalapurakal JA, Breslow NE. Pregnancy outcome after treatment for Wilms tumor: a report from the National Wilms Tumor Study Group. J Clin Oncol. 2002;20(10):2506-2513.

29. Green DM, Lange JM, Peabody EM, et al. Pregnancy outcome after treatment for Wilms tumor: a report from the national Wilms tumor long-term follow-up study. J Clin Oncol. 2010;28(17):2824-2830.

30. Green DM, Sklar CA, Boice JD Jr, et al. Ovarian failure and reproductive outcomes after childhood cancer treatment: results from the Childhood Cancer Survivor Study. J Clin Oncol. 2009;27(14):2374-2381.

31. Lutchman Singh K, Davies M, Chatterjee R. Fertility in female cancer survivors: pathophysiology, preservation and the role of ovarian reserve testing. Hum Reprod Update. 2005;11(1):69-89.

32. van Disseldorp J, Lambalk CB, Kwee J, et al. Comparison of inter- and intra-cycle variability of anti-Mullerian hormone and antral follicle counts. Hum Reprod. 2010;25(1):221-227.

33. Lie Fong S, Laven JS, Hakvoort-Cammel FG, et al. Assessment of ovarian reserve in adult childhood cancer survivors using anti-Müllerian hormone. Hum Reprod. 2009;24(4):982-990.

34. Decanter C, Morschhauser F, Pigny P, Lefebvre C, Gallo C, Dewailly D. Anti-Müllerian hormone follow-up in young women treated by chemotherapy for lymphoma: preliminary results. Reprod Biomed Online. 2010;20(2):280-285.
35. Stern C. Future fertility for young women with cancer: protection, preservation, or both? In: Kovacs G, editor. How to Improve Your ART Success Rates: An Evidence-Based Review of Adjuncts to IVF. Cambridge, UK: Cambridge University Press; 2011:226-234.

36. Noyes N, Porcu E, Borini A. Over 900 oocyte cryopreservation babies born with no apparent increase in congenital anomalies. Reprod Biomed Online. 2009;18(6):769-776.

37. Cobo A, Diaz C. Clinical application of oocyte vitrification: a systematic review and meta-analysis of randomized controlled trials. Fertil Steril. 2011;96(2):277-285.

38. Gook DA, Edgar DH. Human oocyte cryopreservation. Hum Reprod Update. 2007:13(6):591-605.

39. Humaidan P, Quartarolo J, Papanikolaou EG. Preventing ovarian hyperstimulation syndrome: guidance for the clinician. Fertil Steril. 2010;94(2):389-400.

40. Junk SM, Yeap D. Improved implantation and ongoing pregnancy rates after single-embryo transfer with an optimized protocol for in vitro oocyte maturation in women with polycystic ovaries and polycystic ovary syndrome. Fertil Steril. 2012;98(4):888-892.

41. Silber SJ, Woodruff TK, Shea LD. To transplant or not to transplant that is the question. Cancer Treat Res. 2010;156:41-54.

42. Jansen FW, Kolkman W, Bakkum EA, de Kroon CD, Trimbos-KemperTC, Trimbos JB. Complications of laparoscopy: an inquiry about closed- versus open-entry technique. Am J Obstet Gynecol. 2004; 190(3):417-422.

43. Schmidt KL, Andersen CY, Loft A, Byskov AG, Ernst E, Andersen AN. Follow-up of ovarian function post-chemotherapy following ovarian cryopreservation and transplantation. Hum Reprod. 2005;20(12): 3539-3546.

44. Gook DA, Edgar DH, Borg J, et al. Oocyte maturation, follicle rupture and luteinisation in human cryopreserved ovarian tissue following xenografting. Hum Reprod. 2003;18(9):1772-1781.

45. Demeestere I, Simon P, Emiliani S, Delbaere A, Englert Y. Orthotopic and heterotopic ovarian tissue transplantation. Hum Reprod Update. 2009;15(6):649-665.

46. Domans MM, Donnez J, Camboni A, et al. IVF outcome in patients with orthotopically transplanted ovarian tissue. Hum Reprod. 2009; 24(11):2778-2787.

47. Demeestere I, Basso O, Moffa F, Peccatori F, Poirot C, Shalom-Paz E. Fertility preservation in female cancer patients. Obstet Gynecol Int. Epub October 20, 2012.

48. Donnez J, Dolmans MM, Demylle D, et al. Livebirth after orthotopic transplantation of cryopreserved ovarian tissue. Lancet. 2004; 364(9443): 1405-1410.

49. Dittrich R, Lotz L, Keck G, et al. Live birth after ovarian tissue autotransplantation following overnight transportation before cryopreservation. Fertil Steril. 2012;97(2):387-390.

50. Donnez J, Silber S, Andersen CY, et al. Children born after autotransplantation of cryopreserved ovarian tissue. A review of 13 live births. Ann Med. 2011;43(6):437-450.

51. Revel A, Laufer N, Ben Meir A, Lebovich M, Mitrani E. Micro-organ ovarian transplantation enables pregnancy: a case report. Hum Reprod. 2011;26(5):1097-1103.

52. Silber SJ. Ovary cryopreservation and transplantation for fertility preservation. Mol Hum Reprod. 2012;18(2):59-67.

53. Martínez F, Devesa M, Coroleu B, et al. Cancer and fertility preservation: Barcelona consensus meeting. Gynecol Endocrinol. 2013; 29(4):285-291.

54. Andersen CY, Silber SJ, Berghold SH, Jorgensen JS, Ernst E. Long-term duration of function of ovarian tissue transplants: case reports. Reprod Biomed Online. 2012;25(2):128-132.

55. Silber S, Kagawa N, Kuwayama M, Gosden R. Duration of fertility after fresh and frozen ovary transplantation. Fertil Steril. 2010;94(6): 2191-2196.

56. Meirow D, Hardan I, Dor J, et al. Searching for evidence of disease and malignant cell contamination in ovarian tissue stored from hematologic cancer patients. Hum Reprod. 2008;23(5):1007-1013.

57. Rosendahl M, Andersen MT, Ralfkiær E, Kjeldsen L, Andersen MK, Andersen CY. Evidence of residual disease in cryopreserved ovarian cortex from female patients with leukemia. Fertil Steril. 2010;94(6):2186-2190. 
58. Greve T, Clasen-Linde E, Andersen MT, et al. Cryopreserved ovarian cortex from patients with leukemia in complete remission contains no apparent viable malignant cells. Blood. 2012;120(22): 4311-4316.

59. Seshadri T, Gook D, Lade S, et al. Lack of evidence of disease contamination in ovarian tissue harvested for cryopreservation from patients with Hodgkin lymphoma and analysis of factors predictive of oocyte yield. Br J Cancer. 2006;94(7):1007-1010.

60. Salle B, Demirci B, Franck M, Rudigoz RC, Guerin JF, Lornage J. Normal pregnancies and live births after autograft of frozen-thawed hemi-ovaries into ewes. Fertil Steril. 2002;77(2):403-408.

61. Bedaiwy MA, Shahin AY, Falcone T. Reproductive organ transplantation: advances and controversies. Fertile Steril. 2008;90(6):2031-2055.

62. Huang JY, Tulandi T, Holzer H, Tan SL, Chian RC. Combining ovarian tissue cryobanking with retrieval of immature oocytes followed by in vitro maturation and vitrification: an additional strategy of fertility preservation. Fertil Steril. 2008;89(3):567-572.

63. Xu M, Barrett SL, West-Farrell E, et al. In vitro grown human ovarian follicles from cancer patients support oocyte growth. Hum Reprod. 2009;24(10):2531-2540.

64. Blumenfeld Z, von Wolff M. GnRH-analogues and oral contraceptives for fertility preservation in women during chemotherapy. Hum Reprod Update. 2008;14(6):543-552.

65. Meirow D, Assad G, Dor J, Rabinovici J. The GnRH antagonist cetrorelix reduces cyclophosphamide-induced ovarian follicular destruction in mice. Hum Reprod. 2004;19(6):1294-1299.

66. Beck-Fruchter R, Weiss A, Shalev E. GnRH agonist therapy as ovarian protectants in female patients undergoing chemotherapy: a review of the clinical data. Hum Reprod Update. 2008;14(6):553-561.

67. Clowse ME, Behera MA, Anders CK, et al. Ovarian preservation by GnRH agonists during chemotherapy: a meta-analysis. JWomens Health (Larchmt). 2009;18(3):311-319.

68. Bedaiwy MA, Abou-Setta AM, Desai N, et al. Gonadotropin-releasing hormone analog cotreatment for preservation of ovarian function during gonadotoxic chemotherapy: a systematic review and meta-analysis. Fertil Steril. 2011;95(3):906-914.

69. Gerber B, von Minckwitz G, Stehle H, et al; German Breast Group Investigators. Effect of luteinizing hormone-releasing hormone agonist on ovarian function after modern adjuvant breast cancer chemotherapy: the GBG 37 ZORO study. J Clin Oncol. 2011;29(17): 2334-2341.

70. Fishel Bartal M, Carmely A, Kalechman Y, Sredni B, Meirow D. The protective effect of the immunomodulator AS101 against chemotherapy-induced female reproductive damage. IMAJ 2009; 11:575-576.

71. Kerr JB, Hutt KJ, Michalak EM, et al. DNA damage-induced primordial follicle oocyte apoptosis and loss of fertility require TAp63-mediated induction of Puma and Noxa. Mol Cell. 2012;48(3):343-352.

72. Morice P, Juncker L, Rey A, El-Hassan J, Haie-Meder C, Castaigne D. Ovarian transposition for patients with cervical carcinoma treated by radiosurgical combination. Fertil Steril. 2000;74(4):743-748.

73. Lee SJ, Schover LR, Partridge AH, et al. American Society of Clinical Oncology recommendations on fertility preservation in cancer patients. J Clin Oncol. 2006;24(18):2917-2931.

74. Kenney LB, Laufer MR, Grant FD, Grier H, Diller L. High risk of infertility and long term gonadal damage in males treated with high dose cyclophosphamide for sarcoma during childhood. Cancer. 2001;91(3):613-621.

75. van Casteren NJ, van der Linden GH, Hakvoort-Cammel FG, Hählen K, Dohle GR, van den Heuvel-Eibrink MM. Effect of childhood cancer treatment on fertility markers in adult male long-term survivors. Pediatr Blood Cancer. 2009;52(1):108-112.

76. van Alphen MM, van de Kant HJ, de Rooij DG. Depletion of the spermatogonia from the seminiferous epithelium of the rhesus monkey after X irradiation. Radiat Res. 1988;113(3):473-486.

77. de Rooij DG, van de Kant HJ, Dol R, et al. Long-term effects of irradiation before adulthood on reproductive function in the male rhesus monkey. Biol Reprod. 2002;66(2):486-494.
78. Howell SJ, Shalet SM. Spermatogenesis after cancer treatment: damage and recovery. J Natl Cancer Inst Monogr. 2005;34:12-17.

79. Anserini P, Chiodi S, Spinelli S, et al. Semen analysis following allogeneic bone marrow transplantation. Additional data for evidencebased counselling. Bone Marrow Transplant. 2002;30(7):447-451.

80. Sklar CA, Robison LL, Nesbit ME, et al. Effects of radiation on testicular function in long-term survivors of childhood acute lymphoblastic leukemia: a report from the Children Cancer Study Group. J Clin Oncol. 1990;8(12):1981-1987.

81. Shalet SM, Tsatsoulis A, Whitehead E, Read E. Vulnerability of the human Leydig cell to radiation damage is dependent upon age. J Endocrinol. 1989;120(1):161-165.

82. Brauner R, Czernichow P, Cramer P, Schaison G, Rappaport R. Leydigcell function in children after direct testicular irradiation for acute lymphoblastic leukemia. $N$ Engl J Med. 1983;309(1):25-28.

83. Heikens J, Behrendt H, Adriaanse R, Berghout A. Irreversible gonadal damage in male survivors of pediatric Hodgkin's disease. Cancer. 1996;78(9):2020-2024.

84. Brämswig JH, Heimes U, Heiermann E, Schlegel W, Nieschlag E, Schellong G. The effects of different cumulative doses of chemotherapy on testicular function. Results in 75 patients treated for Hodgkin's disease during childhood or adolescence. Cancer. 1990;65(6):1298-1302.

85. Wallace WH, Anderson RA, Irvine DS. Fertility preservation for young patients with cancer: who is at risk and what can be offered? Lancet Oncol. 2005;6(4):209-218.

86. Aubier F, Flamant F, Brauner R, Caillaud JM, Chaussain JM, Lemerle J. Male gonadal function after chemotherapy for solid tumors in childhood. J Clin Oncol. 1989;7(3):304-309.

87. Nurmio M, Keros V, Lähteenmäki P, Salmi T, Kallajoki M, Jahnukainen K. Effect of childhood acute lymphoblastic leukemia therapy on spermatogonia populations and future fertility. $J$ Clin Endocrinol Metab. 2009;94(6):2119-2122.

88. Ridola V, Fawaz O, Aubier F, et al. Testicular function of survivors of childhood cancer: a comparative study between ifosfamide- and cyclophosphamide-based regimens. Eur J Cancer. 2009;45(5): 814-818.

89. Meistrich ML, Wilson G, Brown BW, da Cunha MF, Lipshultz LI. Impact of cyclophosphamide on long-term reduction in sperm count in men treated with combination chemotherapy for Ewing and soft tissue sarcomas. Cancer. 1992;70(11):2703-2712.

90. Rivkees SA, Crawford JD. The relationship of gonadal activity and chemotherapy-induced gonadal damage. JAMA. 1988;259(14): 2123-2125.

91. Gurgan T, Salman C, Demirol A. Pregnancy and assisted reproduction techniques in men and women after cancer treatment. Placenta. 2008;29 Suppl B:152-159.

92. Wyns C, Curaba M, Vanabelle B, Van Langendonckt A, Donnez J. Options for fertility preservation in prepubertal boys. Hum Reprod Update. 2010;16(3):312-328.

93. Kreuser ED, Xiros N, Hetzel WD, Heimpel H. Reproductive and endocrine gonadal capacity in patients treated with COPP chemotherapy for Hodgkin's disease. J Cancer Res Clin Oncol. 1987;113(3): 260-266.

94. Bokemeyer C, Schmoll HJ, van Rhee J, Kuczyk M, Schuppert F, Poliwoda H. Long-term gonadal toxicity after therapy for Hodgkin's and non-Hodgkin's lymphoma. Ann Hematol. 1994;68(3): $105-110$.

95. Waxman J. Chemotherapy and the adult gonad: a review. $J R$ Soc Med. 1983;76(2):144-148.

96. Waxman J, Terry Y, Rees LH, Lister TA. Gonadal function in men treated for acute leukaemia. Br Med J (Clin Res Ed). 1983;287(6399): 1093-1094.

97. Centola GM, Keller JW, Henzler M, Rubin P. Effect of low-dose testicular irradiation on sperm count and fertility in patients with testicular seminoma. J Androl. 1994;15(6):608-613.

98. Ash P. The influence of radiation on fertility in man. $\mathrm{Br} J$ Radiol. 1980;53(628):271-278. 
99. Rowley MJ, Leach DR, Warner GA, Heller CG. Effect of graded doses of ionizing radiation on the human testis. Radiat Res. 1974;59(3): 665-678.

100. Sarafoglou K, Boulad F, Gillio A, Sklar C. Gonadal function after bone marrow transplantation for acute leukemia during childhood. J Pediatr. 1997;130(2):210-216.

101. Bahadur G, Ling KL, Hart R, et al. Semen quality and cryopreservation in adolescent cancer patients. Hum Reprod. 2002;17(12):3157-3161.

102. Kamischke A, Jürgens H, Hertle L, Berdel WE, Nieschlag E. Cryopreservation of sperm from adolescents and adults with malignancies. J Androl. 2004;25(4):586-592.

103. Barak S, Baker HW. Clinical management of male infertility. In: McLachlan R, editor. Endocrinology of Male Reproduction. South Dartmouth, MA: Endotext.org; 2012. Available at: http://www.endotext. org/male/male 7/maleframe7.htm. Accessed April 11, 2013.

104. Agarwal A, Said TM. Role of sperm chromatin abnormalities and DNA damage in male infertility. Hum Reprod Update. 2003;9(4): 331-345.

105. Feldschuh J, Brassel J, Durso N, Levine A. Successful sperm storage for 28 years. Fertil Steril. 2005;84(4):1017.

106. Sharma V. Sperm storage for cancer patients in the UK: a review of current practice. Hum Reprod. 2011;26(11):2935-2943.

107. Brook PF, Radford JA, Shalet SM, Joyce AD, Gosden RG. Isolation of germ cells from human testicular tissue for low temperature storage and autotransplantation. Fertil Steril. 2001;75(2):269-274.

108. Hovatta O. Cryopreservation of testicular tissue in young cancer patients. Hum Reprod Update. 2001;7(4):378-383.

109. Keros V, Rosenlund B, Hultenby K, Aghajanova L, Levkov L, Hovatta O. Optimizing cryopreservation of human testicular tissue: comparison of protocols with glycerol, propanediol and dimethylsulphoxide as cryoprotectants. Hum Reprod. 2005;20(6):1676-1687.

110. Keros V, Hultenby K, Borgström B, Fridström M, Jahnukainen K, Hovatta O. Methods of cryopreservation of testicular tissue with viable spermatogonia in pre-pubertal boys undergoing gonadotoxic cancer treatment. Hum Reprod. 2007;22(5):1384-1395.

111. Stukenborg JB, Schlatt S, Simoni M, et al. New horizons for in vitro spermatogenesis? An update on novel three-dimensional culture systems as tools for meiotic and post-meiotic differentiation of testicular germ cells. Mol Hum Reprod. 2009;15(9):521-529.

112. Sato T, Katagiri K, Gohbara A, et al. In vitro production of functional sperm in cultured neonatal mouse testes. Nature. 2011;471(7339): 504-507.

113. Geens M, Van de Velde H, De Block G, Goossens E, Van Steirteghem A, Tournaye $\mathrm{H}$. The efficiency of magnetic-activated cell sorting and fluorescence-activated cell sorting in the decontamination of testicular cell suspensions in cancer patients. Hum Reprod. 2007;22(3): 733-742.

114. Fujita K, Tsujimura A, Miyagawa Y, et al. Isolation of germ cells from leukemia and lymphoma cells in a human in vitro model: potential clinical application for restoring human fertility after anticancer therapy. Cancer Res. 2006;66(23):11166-11171.

115. Luetjens CM, Stukenborg JB, Nieschlag E, Simoni M, Wistuba J. Complete spermatogenesis in orthotopic but not in ectopic transplants of autologously grafted marmoset testicular tissue. Endocrinology. 2008;149(4):1736-1747.

116. Geens M, De Block G, Goossens E, Frederickx V, Van Steirteghem A, Tournaye H. Spermatogonial survival after grafting human testicular tissue to immunodeficient mice. Hum Reprod. 2006;21(2):390-396.

117. Schlatt S, Honaramooz A, Ehmcke J, et al. Limited survival of adult human testicular tissue as ectopic xenograft. Hum Reprod. 2006;21(2): 384-389.

118. Clinical Oncological Society of Australia. Fertility Preservation for AYAs Diagnosed with Cancer: Guidance for Health Professionals. Sydney: Clinical Oncological Society of Australia; nd [updated October 17, 2012]. Available from: http://wiki.cancer.org.au/australia/ COSA:AYA_cancer_fertility_preservation. Accessed April 11, 2013.

119. National Comprehensive Cancer Network, Clinical Practice Guidelines for Adolescents and Young Adults (AYA) with cancer. 2012, National Comprehensive Cancer Network: Washington.
120. Fallat ME, Hutter J; American Academy of Pediatrics Committee on Bioethics; American Academy of Pediatrics Section on Hematology/ Oncology; American Academy of Pediatrics Section on Surgery. Preservation of fertility in pediatric and adolescent patients with cancer. Pediatrics. 2008;121(5):e1461-e1469.

121. Anderson RA, Weddell A, Spoudeas HA, et al. Do doctors discuss fertility issues before they treat young patients with cancer? Hum Reprod. 2008;23(10):2246-2251.

122. Klosky JL, Randolph ME, Navid F, et al. Sperm cryopreservation practices among adolescent cancer patients at risk for infertility. Pediatr Hematol Oncol. 2009;26(4):252-260.

123. Forman EJ, Anders CK, Behera MA. Pilot survey of oncologists regarding treatment-related infertility and fertility preservation in female cancer patients. J Reprod Med. 2009;5(4):203-207.

124. Mitchell W, Clarke S, Sloper P. Care and support needs of children and young people with cancer and their parents. Psychooncology. 2006;15(9):805-816

125. Zebrack BJ, Zeltzer LK, Whitton J, et al. Psychological outcomes in long-term survivors of childhood leukemia, Hodgkin's disease, and non-Hodgkin's lymphoma: a report from the Childhood Cancer Survivor Study. Pediatrics. 2002;110(1 Pt 1):42-52.

126. Schover LR. Patient attitudes toward fertility preservation. Pediatric Blood Cancer. 2009;53(2):281-284.

127. Borgmann-Staudt A, Rendtorff R, Reinmuth S, et al. Fertility after allogeneic haematopoietic stem cell transplantation in childhood and adolescence. Bone Marrow Transplant. 2012;47(2):271-276.

128. Chapple A, Salinas M, Ziebland S, et al. Fertility issues: the perceptions and experiences of young men recently diagnosed and treated for cancer. J Adolesc Health. 2007;40(1):69-75.

129. Saito K, Suzuki K, Iwasaki A, Yumura Y, Kubota Y. Sperm cryopreservation before cancer chemotherapy helps in the emotional battle against cancer. Cancer. 2005;104(3):521-524.

130. Crawshaw M, Sloper P. 'Swimming against the tide' - the influence of fertility matters on the transition to adulthood or survivorship following adolescent cancer. Eur J Cancer Care (Engl). 2010;19(5): 610-620.

131. Wilkes S, Coulson S, Crosland A, Rubin G, Stewart J. Experience of fertility preservation among younger people diagnosed with cancer. Human Fert (Camb). 2010;13(3):151-158.

132. Quinn GP, Vadaparampil ST, Jacobsen PB, et al. Frozen hope: fertility preservation for women with cancer. $J$ Midwifery Womens Health. 2010;55(2):175-180.

133. Pivetta E, Maule MM, Pisani P, et al; Italian Association of Pediatric Hematology and Oncology (AIEOP) Group. Marriage and parenthood among childhood cancer survivors: a report from the Italian AIEOP Off-Therapy Registry. Haematologica. 2011;96(5):744-751.

134. Madanat LM, Malila N, Dyba T, et al. Probability of parenthood after early onset cancer: a population-based study. Int J Cancer. 2008; 123(12):2891-2898.

135. Zebrack BJ, Casillas J, Nohr L, Adams H, Zeltzer LK. Fertility issues for young adult survivors of childhood cancer. Psychooncology. 2004;13(10):689-699.

136. Oosterhuis BE, Goodwin T, Kiernan M, Hudson MM, Dahl GV. Concerns about infertility risks among pediatric oncology patients and their parents. Pediatr Blood Cancer. 2008;50(1):85-89.

137. Quinn GP, Murphy D, Knapp C, et al. Who decides? Decision making and fertility preservation in teens with cancer: a review of the literature. J Adolesc Health. 2011;49(4):337-346.

138. Burns KC, Boudreau C, Panepinto JA. Attitudes regarding fertility preservation in female adolescent cancer patients. J Pediatr Hematol Oncol. 2006;28(6):350-354.

139. Knapp C, Quinn G. Assessing the reproductive concerns of children and adolescents with cancer: challenges and potential solutions. J Adolesc Young Adult Oncol. 2011;1(1):31-35.

140. Wallace WH, Critchely HO, Anderson RA. Optimizing reproductive outcome in children and young people with cancer. $J$ Clin Oncol. 2012;30(1):3-5. 
141. Wuchty S, Jones BF, Uzzi B. The increasing dominance of teams in production of knowledge. Science. 2007;36(36):1036-1039.

142. Gardino SL, Jeruss JS, WoodruffTK. Using decision trees to enhance interdisciplinary team work: the case of oncofertility. J Assist Reprod Genet. 2010;27(5):227-231.

143. Scott-Trainer J. The role of a patient navigator in fertility preservation. In: WoodruffTK, Zoloth L, Campo-Engelstein L, Rodriguez S, editors. Oncofertility. Berlin and Heidelberg: Springer; 2010:469-470.

144. Jona K, Gerber A. MyOncofertility.org: a web-based patient education resource supporting decision making under severe emotional and cognitive overload. In: Woodruff TK, Zoloth L, Campo-Engelstein L, Rodriguez S, editors. Oncofertility. Berlin and Heidelberg: Springer; 2010:345-361.

145. Aleem IS, Jalal H, Aleem IS, Sheikh AA, Bhandari M. Clinical decision analysis: incorporating the evidence with patient preferences. Patient Prefer Adherence. 2009;3(1):21-24.

146. Hunink MG, Glasziou P, Siegel J, et al. Decision Making in Health and Medicine: Integrating Evidence and Values. Cambridge, UK: Cambridge University Press; 2001.

147. Frosch DL, Kaplan RM, Felitti VJ. A randomized controlled trial comparing internet and video to facilitate patient education for men considering the prostate specific antigen test. J Gen Intern Med. 2003;18(10):781-787.

148. Grundy R, Gosden RG, Hewitt M, et al. Fertility preservation for children treated for cancer (1): scientific advances and research dilemmas. Arch Dis Child. 2001;84(4):355-359.

149. Grundy R, Larcher V, Gosden RG, et al. Fertility preservation for children treated for cancer (2): ethics of consent for gamete storage and experimentation. Arch Dis Child. 2001;84(4):360-362.

150. Albertini DF. Preserving integrity, along with fertility. JAssist Reprod Genet. 2012;29(6):463-464.

151. Tobias JS. BMJ's present policy (sometimes approving research in which patients have not given fully informed consent) is wholly correct. BMJ. 1997;314(7087):1111-1114.

152. Nuffield Council on Bioethics. Human Tissues: Ethical and Legal Issues. London: Nuffield Council on Bioethics; 1995. Available from: http://www.nuffieldbioethics.org/sites/default/files/Human\%20tissue. pdf. Accessed April 11, 2013.

153. Letourneau JM, Melisko ME, Cedars MI, Rosen MP. A changing perspective: improving access to fertility preservation. Nat Rev Clin Oncol. 2011;8(1):56-60.
154. Waxman JH, Ahmed R, Smith D, et al. Failure to preserve fertility in patients with Hodgkin's disease. Cancer Chemother Pharmacol. 1987;19:159-162.

155. Pereyra Pacheco B, Mendez Ribas JM, Milone G, et al. Use of GnRH analogs for functional protection of the ovary and preservation of fertility during cancer treatment in adolescents: a preliminary report. Gynecol Oncol. 2001;81:391-397.

156. Blumenfeld Z, Eckman A. Preservation of fertility and ovarian function and minimization of chemotherapy-induced gonadotoxicity in young women by GnRH-a. J Natl Cancer Inst Monogr. 2005;34:40-43.

157. Dann EJ, Epelbaum R, Avivi I, et al. Fertility and ovarian function are preserved in women treated with an intensified regimen of cyclophosphamide, adriamycin, vincristine and prednisone (Mega-CHOP) for non-Hodgkin lymphoma. Hum Reprod. 2005;20:2247-2249.

158. Somers EC, Marder W, Christman GM, Ognenovski V, McCune WJ. Use of a gonadotropin-releasing hormone analog for protection against premature ovarian failure during cyclophosphamide therapy in women with severe lupus. Arthritis Rheum. 2005;52:2761-2767.

159. Giuseppe L, Attilio G, Edoardo DN, Loredana G, Cristina L, Vincenzo L. Ovarian function after cancer treatment in young women affected by Hodgkin disease (HD). Hematology. 2007;12:141-147.

160. Badawy A, Elnashar A, El-Ashry M, and Shahat M. Gonadotropin-releasing hormone agonists for prevention of chemotherapy-induced ovarian damage: prospective randomized study. Fertil Steril. 2009;91:694-697.

161. Blumenfeld Z, von Wolff M. GnRH-analogues and oral contraceptives for fertility preservation in women during chemotherapy. Hum Reprod Update. 2008;14:543-552.

162. Sverrisdottir A, Nystedt M, Johansson H, Fornander T. Adjuvant goserelin and ovarian preservation in chemotherapy treated patients with early breast cancer: results from a randomized trial. Breast Cancer Res Treat. 2009;117:561-567.

163. Gerber B, von Minckwitz G, Stehle H, et al. Effect of luteinizing hormone-releasing hormone agonist on ovarian function after modern adjuvant breast cancer chemotherapy: The GBG 37 ZORO study. J Clin Oncol. 2011;29:2334-2341.
Clinical Oncology in Adolescents and Young Adults

\section{Publish your work in this journal}

Clinical Oncology in Adolescents and Young Adults is an international, peer-reviewed, open access journal publishing original research, reports, editorials, reviews and commentaries on all aspects of epidemiology, diagnosis and treatment of cancers in adolescents and young adults. The manuscript management system is completely

\section{Dovepress}

online and includes a very quick and fair peer-review system. Visit http://www.dovepress.com/testimonials.php to read real quotes from published authors.

\footnotetext{
Submit your manuscript here: http://www.dovepress.com/clinical-oncology-in-adolescents-and-young-adults-journal
} 